\title{
In COVID-19 time, how to protect myself and others? a review
}

\author{
Angham G Hadi ${ }^{1}$, Mohammed Kadhom ${ }^{2}$, Emad Yousif ${ }^{3}$, Nany Hairunisa ${ }^{4}$
}

\begin{abstract}
Coronaviruses are a big identified group of viruses that could result in sickness in humans and animals. It was confirmed that many of these viruses caused respiratory diseases among humans and their symptoms range from popular colds to more serious diseases, such as the Middle East respiratory syndrome (MERS) and severe acute respiratory syndrome (SARS). The recently detected Coronavirus (called SARSCoV-2) causes the COVID-19 pandemic, which causes a serious threat worldwide. There was no previous knowledge of this virus before the outbreak of Wuhan city in China in December 2019. However, there is progress in defining, understanding, and dealing with this virus. In this review, we are focusing on the common questions regarding coronavirus transition and spread, and how to prevent the infection.
\end{abstract}

Kata kunci: COVID-19, SARS-CoV-2, coronavirus, symptoms, infection
${ }^{1}$ Department of Chemistry, College of Science, University of Babylon, Babylon, Iraq

${ }^{2}$ Department of Renewable Energy, College of Energy and Environmental Sciences, Alkarkh University of Science, Baghdad, Iraq

${ }^{3}$ Department of Chemistry, College of Science, Al-Nahrain University, Baghdad, Iraq

${ }^{4}$ Department of Occupational Medicine, Faculty of Medicine Universitas Trisakti, Jakarta, Indonesia

\section{Correspondence:}

Emad Yousif

Department of Chemistry, College of Science, Al-Nahrain University, Baghdad, Iraq

Email: emad_yousif@hotmail.com

J Biomedika Kesehat 2020;3(3):153158

DOI: 10.18051/JBiomedKes.2020. v3.153-158

pISSN: 2621-539X / eISSN: 2621-5470

Artikel akses terbuka (open access) ini didistribusikan di bawah lisensi Creative Commons Attribution 4.0 International (CC-BY 4.0) 


\section{ABSTRAK}

\section{Di masa COVID-19, bagaimana cara melindungi diri sendiri dan orang lain?}

Coronavirus adalah kelompok besar virus yang dapat menyebabkan penyakit pada manusia dan hewan. Telah dipastikan bahwa banyak dari virus ini menyebabkan penyakit pernapasan pada manusia dan gejalanya berkisar dari pilek populer hingga penyakit yang lebih serius, seperti sindrom pernapasan Timur Tengah (MERS) dan sindrom pernapasan akut yang parah (SARS). Virus Corona yang baru terdeteksi (disebut SARS-CoV-2) menyebabkan pandemi COVID-19, menyebabkan ancaman serius di seluruh dunia. Belum ada pengetahuan sebelumnya tentang virus ini sebelum merebak di kota Wuhan (China) pada Desember 2019 lalu. Namun, ada kemajuan dalam pendefinisian, pemahaman, dan penanganan virus ini. Dalam ulasan ini, kami berfokus pada pertanyaan umum mengenai transisi dan penyebaran virus corona, serta cara mencegah infeksi.

Keywords: COVID-19, SARS-CoV, coronavirus, gejala, infeksi

\section{INTRODUCTION}

The commonly appeared symptoms of COVID-19 are fatigue, fever, and dry cough. ${ }^{(1-3)}$ Nevertheless, several patients could have aches, pain, sore throat, cold, nasal congestion, and/or diarrhea. The symptoms start mild and then either decrease or increase depending on, basically, the patient's immunity system. It was found that several individuals get infected without presenting any symptoms and feeling ill. Around 4 out of 5 people could recover without the necessity for intensive care. Here, in the regular conditions, approximately $15-20 \%$ of people who develop the infection and suffer from hard breath get in serious conditions. The risk is higher with elders and those of chronic health issues, such as diabetes, heart diseases, and high blood pressure. ${ }^{(4-8)}$ Around 2\% of people who got the infection have died. It is recommended for people with symptoms of fever, coughing, and hard breath to seek medical help. ${ }^{(1)}$

People could get the COVID-19 infection by contact with other people who are already infected whether the symptoms appear or not. The epidemic could transmit among people via the tiny droplets that scatter from the mouth or nose of the infected person while coughing or sneezing. ${ }^{(9-13)}$ These droplets settle down on the object's surfaces that surround the patient. Thereby, other people could later get COVID-19 once they contact these contaminated objects or surfaces and later touch their eyes, noses, and/or mouths. More commonly, people get infected when they breathe the patient's exhalation and cough droplets. Here, it is important to keep at least one meter (around 3 feet) social distancing from other people, especially the sick persons. Studies carried out up to date indicate that SARS-CoV-2 is primarily transferring once people being in contact with the droplets that came out from an infected person that could spread in the surrounding. ${ }^{(11-13)}$

The major way of spreading COVID-19 is the respiratory droplets that come out once the patient coughs. The danger of this disease is represented by the asymptomatic symptoms, where the infected person transmits the disease without any knowledge. However, the majority of infected people have only mild conditions, especially at the early stages of the disease. Thereby, the disease can transmit by an infected individual who has a moderate cough but has low sickness feeling. The WHO conducts researches in investing the transmission principles and keeps people informed of the latest findings. ${ }^{(14)}$

\section{How can I protect myself and prevent spreading COVID-19?}

Since this virus is novel and much information about it were missing, keeping up with the latest information is required to understand how to deal with this disease. Information from global websites, as the WHO website, and local websites issued by your country's national and local public health authorities should be dependable. (15-17) Almost all countries have reported cases of COVID-19, and many experienced outbreaks. However, the relevant authorities in China, the origin of this virus, and several countries slowed down the spread of the outbreak or completely stopping it. Since it is difficult to predict the development of the situation, it is recommended to regularly check the latest findings and approaches. $(18-20)$

Individuals can reduce the risk of developing COVID-19 disease or its spread by practicing the following simple actions, such as cleaning hands regularly by rubbing them with hand sanitizers that contain alcohol or rinse them with soap and water for at least $20 \mathrm{sec}$. Also, it 
is recommended to keep a social distance no less than 3 feet among individuals and farther than individuals who have coughing and/or sneezing. Since the sickness symptoms could take a while to appear or could not appear at all, it is recommended to keep a social distancing on all occasions with all people. ${ }^{(19-20)}$

Avoiding touching the mouth, nose, and eyes is highlighted. Hands could be in contact with surfaces that could have viruses. Once the hands got the virus, they may transmit it to the mouth, nose, and/or eyes. SARS-CoV-2 could enter the human body through these outlets and make people ill. It is important to ensure that individuals follow good respiratory hygiene practices. For instance, it is needed to cover the nose and mouth with a tissue or bending the elbow while coughing and/or sneezing, and instantly dispose of the used tissue. Because the droplets spread the virus. Practicing good respiratory habits and etiquette could help to protect people from viruses such as cold viruses, influenza, and COVID-19. ${ }^{(21)}$

Staying home could be the best option if the person feels sick and has a fever, cough, and/ or breathing difficulty. Also, it is recommended to seek medical help and pre-contact the health provider prior to visiting the clinic and pursue the health authorities' instructions. The most updated information about your area's situation are available to national and local authorities. Your primary healthcare provider will guide you quickly to the appropriate health care providers. This could protect individuals and stop spreading the virus and the following consequences. Being aware of the latest updates of the disease and infection places is advised. Follow the health care provider advice, national and local public health authorities, and the career rules on how to protect yourself and others from COVID-19 disease. The national and local authorities are the best placed to advise on what actions people in your area can take to protect themselves. It is recommended to avoid the high infection places, particularly the individual is an elderly person, have diabetes, or heart or respiratory illnesses..$^{(13,18-21)}$

\section{What are the chances for individuals to develop COVID-19 disease?}

The danger is depending on where the individual is at, and more a specific question, is
COVID-19 infection spreading there. In general, the risk of developing COVID-19 infection remains low in most places. ${ }^{(22)}$ However, there are some places across the globe (cities or regions) where the pandemic is currently prevailing. The risk of developing COVID-19 infection is higher for people who live in or visit these areas. Governments and health authorities are now taking serious restrictions whenever a new case of COVID-19 is revealed. It is important to react with all restrictions imposed locally on traveling, transportation, big grouping, etc. Cooperation with the health care agencies who are in charge with disease control would reduce its risk and spread.

COVID-19 outbreaks could be contained and the infection could be stopped as demonstrated by China and some other countries. It is unfortunate that new outbreaks can start very quickly, such as what happened in Iraq in Jun 2020. Hence, it is important to know the situation of the places before intending to visit. WHO frequently publishes the latest information on the status of COVID-19 infection. ${ }^{(23)}$

\section{Should I be concerned about COVID-19 disease?}

The disease caused bySARS-CoV-2 infection is generally mild, particularly in children, teens, and young. However, this virus could result in a serious illness, as about 1 in 5 people with this disease need hospital care as the age of the patient is higher. Therefore, it is rational for people to be concerned about how this disease affects their lives. ${ }^{(13-15)}$ We can properly change our concerns to actions in order to protect ourselves, families, and local communities. One of the best protection actions is regular and extensive hand-washing. Second, meeting and consulting with the local health authorities are important to understand the situation. Third, having good respiratory practices, consuming healthy food, conducting sports, and avoiding smoking are valuable to the immunity system. Finally, keeping a social distancing, including restrictions that may be imposed on travel, movement, and gatherings, could be the main solution for this pandemic. ${ }^{(24)}$

\section{Can antibiotics prevent or treat COVID-19?}

The short answer is no; antibiotics can't treat viruses but bacterial infections. Because 
COVID-19 has resulted from the SARS-CoV-2 virus, antibiotics have no impact on it. Antibiotics are only used if the physician prescribes them and with his/her instructions, commonly prescribed for bacterial infections. However, secondary bacterial infection in COVI-19 patients could be treated by antibiotics. ${ }^{(25-27)}$

\section{Is there any medication or vaccine for COVID-19?}

While some western, traditional, or home medicines could mitigate some of COVID19'ssymptoms, no confirmed medication or vaccine, yet, was assigned to prevent or treat this disease. However, infected people need to be treated to decrease the symptoms, where those with severe sickness need to be hospitalized; fortunately, the majority of patients heal after supportive treatment. WHO does not recommend self-medication, whatever the used medication is, to prevent or treat COVID-19. Nevertheless, there are underway clinical trials that mix western and eastern medicines; global authorities are taking the responsibility to post updated information in this regard. Some potential vaccines and drugs are being investigated to treat this disease. ${ }^{(28)}$ They are being tested through clinical trials. WHO coordinates efforts to develop vaccines and medicines to prevent and treat COVID-19.

\section{Is COVID-19 virus the same as SARS's one?}

The COVID-19 virus (SARS-CoV-2) is not the same as the first SARS virus. However, there is a genetic similarity between the SARSCoV-2 virus (that causes Covid-19) and the first SARS virus, but they are different. SARS is more deadly than COVID-19, but it is much less infectious. No place in the world faced a SARS outbreak since 2003. . $^{(29-31)}$

\section{Is face mask required to protect myself?}

At the beginning of the disease, it was recommended to not wear masks unless the individual has obvious symptoms of COVID-19 (especially coughing) or those who take care of the infected people. ${ }^{(32-34)}$ This came from that an individual can use the single-use mask only once, so if he/she is not sick or not dealing with a sick person, it will be an unnecessarily waste of masks.
However, due to the spread of the disease, it is possible that wearing masks became mandatory for all people to stop this scary increase in infection numbers. Known the lack of masks supplies globally, the WHO is urging people to be wise to use them, the organization recommends a rational use of masks. ${ }^{(13,23)}$

\section{How to use, remove, and dispose a mask?}

Before using the mask, the hands should be clean by rubbing them by an alcoholic cleanser and hand sanitizer, or rinsing them with soap and water. Check the mask if it is deformation, torn, or have holes and identify the top side of the mask (the location of the metal strip (nose bridge)), where the colored side of the mask should be outside. Put the mask on the face, and press on the nose bridge to have the nose's form; drag the mask down until fully cover the mouth, reaching to the chin. After using the mask, remove it by taking off the bands backward the ears holding the mask as far as possible away from the face and clothes to avoid touching the possibly contaminated mask areas. Throw the used mask away in a closed waste bin right after the use. Finally, clean hands after handling the mask by an alcoholic antiseptic or with soap and water. ${ }^{(23,35)}$

\section{Could animals transfer the Covid-19 infection to humans?}

Coronaviruses are an identified group that is commonly recognized in animals, particularly in bats. However, humans are seldom got infected with this type of viruses; but once this happens, they transmit it to other people. For instance, SARS was associated with civet cats and MERS was with camels. Here, the possible animal origin of COVID-19 is still undefined yet. In order to obtain maximum protection, for example, when visiting live animal markets, it is recommended to avert direct contact with animals and surfaces. Also, it is needed to pursue healthy food habits not only during pandemic times especially when dealing with raw meat, animal organs, and milk, and avoid eating raw or undercooked animal products. This could help to prevent uncooked food contamination. ${ }^{(36)}$ 


\section{How long could SARS-CoV-2 stay alive on surfaces?}

The duration in which the virus can stay alive on surfaces is still unidentified, though, it looks like to be similar to other coronaviruses. Researches indicated that coronaviruses, such as SARS-CoV-2, could survive on surfaces from hours up to a few days ${ }^{(37-39)}$; this could differ based on many conditions (such as surface type, surface raw material, ambient temperature and humidity, etc.). If a surface is doubtful to be contaminated, it is recommended to clean it first with the common disinfectant to terminate the virus. Then, cleaning hands by alcoholic cleaners or washing them with soap and water. At that time, avert touching nose, mouth, and eyes. ${ }^{(37)}$

\section{CONCLUSION}

The virus that causes COVID-19 disease (SARS-CoV-2) is mainly transmitted by droplets emitted by the infected person when sneezes, coughs, and speaks. The weight of these droplets is too heavy for them to remain suspended in air; they soon settle down on the ground or surfaces. The virus infection can be transmitted by inhalation if the individual is being within one meter of an infected person. The other way of infection is touching a contaminated surface and then touching eyes, nose, and mouth. It is recommended to keep a social distance among people, wearing masks, avoiding being in touch with the infected people, and never go out unless there is a necessity to do so.

\section{REFERENCES}

1. Jiang F, Deng L, Zhang L, et al. Review of the clinical characteristics of coronavirus disease 2019 (COVID-19). Journal of general internal medicine. 2020; 35(5):1545-1549. doi: 10.1007/ s11606-020-057621-5

2. Ainane T. Moroccan traditional treatment for fever and influenza, similar to symptoms of coronavirus COVID-19 disease: Mini Review. Journal of Analytical Sciences and Applied Biotechnology. 2020;2(1):1-3. doi: 10.5281/zenodo.3908513

3. Lima CMAO. Information about the new coronavirus disease (COVID-19). Radiol Bras. 2020 Mar-Apr;53(2):V-VI. doi: 10.1590/01003984.2020.53.2e1

4. Hajar R. Risk Factors for Coronary Artery Disease: Historical Perspectives. Heart Views. 2017;18(3):109-114. doi: 10.4103/ HEARTVIEWS.HEARTVIEWS_106_17

5. Xu L, Yaqian M, Chen G. Risk factors for severe corona virus disease 2019 (COVID-19) patients: a systematic review and meta analysis. medRxiv. 2020. doi: $10.1101 / 2020.03 .30 .20047415$

6. European Centre for Disease Prevention and Control. Rapid Risk Assessment Coronavirus disease 2019 (COVID-19) in the EU/EEA and the UK-ninth update [Internet]. Stockholm: 2020; European Centre for Disease Prevention and Control. Available from: https://www.ecdc.europa. eu/en/publications-data/rapid-risk-assessmentcoronavirus-disease-2019-covid-19-pandemicninth-update

7. Covid C, Team R. Severe outcomes among patients with coronavirus disease 2019 (COVID-19) United States, February 12-March 16, 2020. MMWR Morb Mortal Wkly Rep. 2020; 69(12), 343-346. doi: 10.15585/mmwr.mm6912e2.

8. Ryan D, Ravussin E, Heymsfield S. COVID 19 and the patient with obesity-the editors speak out. Obesity (Silver Spring, Md.).t 2020;28(5):847-847. doi: $10.1002 /$ oby. 22808

9. Wimalawansa S. Global Epidemic of Coronavirus-Covid-19: What Can We Do to Minimize Risks [Internet]. European Journal of Biomedical and Pharmaceutical Sciences. 2020;7(3):432-438. Available from: https://www. ejbps.com/ejbps/abstract_id/6656

10. Chavez S, Long B, Koyfman A, et al. Coronavirus Disease (COVID-19): A primer for emergency physicians. Am J Emerg Med. 2020 Mar 24:S0735-6757(20)30178-9. doi: 10.1016/j. ajem.2020.03.036

11. Helmy YA, Fawzy M, Elaswad A, et al. The COVID-19 Pandemic: A Comprehensive Review of Taxonomy, Genetics, Epidemiology, Diagnosis, Treatment, and Control. J Clin Med. 2020;9(4):1225. doi: 10.3390/jcm9041225

12. Dhand R, Li J. Coughs and Sneezes: Their Role in Transmission of Respiratory Viral Infections, Including SARS-CoV-2. Am J Respir Crit Care Med. 2020;202(5):651-659. doi: 10.1164/ rccm.202004-1263PP

13. Hadi A, Kadhom M, Hairunisa N, et al. A Review on COVID-19: Origin, Spread, Symptoms, Treatment, and Prevention. Biointerface Research in Applied Chemistry. 2020;10(6):7234-42. doi: 10.33263/BRIAC106.72347242

14. Unal M, Irez T. COVID 19 Disease Caused by Coronavirus 2 (SARS-CoV-2)(Severe Acute Respiratory Syndrome). Asian Journal of Medicine and Health. 2020;18(4):1-11. doi: 10.9734/ ajmah/2020/v18i430194

15. Al-mashhadani M, Alsayed R, Hussain Z, et al. An Overview of Possible Therapeutic Approaches Against Novel Coronavirus Disease 2019 Pandemic. Al-Nahrain Journal of Science. 2020; Special Issue: COVID-19, 6-11.] doi: 10.22401/ ANJS.00.3.02

16. Semple S, Cherrie J. COVID-19: protecting worker health. Annals of work exposures and health. 2020; 64(5): 461-464. doi: 10.1093/annweh/wxaa033

17. Huh, S. How to train the health personnel for protecting themselves from novel coronavirus (COVID-19) infection during their patient or suspected case care. Journal of educational evaluation for health professions. 2020;17:10. doi: 


\subsection{2/jeehp.2020.17.10}

18. French M, Monahan T. Dis-ease Surveillance: How Might Surveillance Studies Address COVID-19?. Surveillance \& Society. 2020;18(1):1-11. doi: 10.24908/ss.v18i1.13985

19. Kirkpatrick J, Mitchell C, Taub C, et al. ASE statement on protection of patients and echocardiography service providers during the 2019 novel coronavirus outbreak. Journal of the American College of Cardiology. 2020;;75(24):3078-84. doi: 10.1016/j. echo.2020.04.001

20. Greenhalgh T, Schmid M, Czypionka T, et al. Face masks for the public during the covid-19 crisis. BMJ. 2020 Apr 9;369:m1435. doi: 10.1136/bmj. m1435

21. Jones L, Walsh K, Willcox $\mathrm{M}$, et al. The COVID-19 pandemic: Important considerations for contact lens practitioners. Contact Lens and Anterior Eye.) 2020;43(3):196-203. doi: 10.1016/j. clae.2020.03.012

22. World Health Organization. Coronavirus disease 2019 (COVID-19): situation report, 72 [Internet]. World Health Organizatio; 2020. Available from: https://www.who.int/docs/default-source/ coronaviruse/situation-reports/20200401-sitrep72-covid-19.pdf?sfvrsn=3dd8971b 2

23. Sun J, He WT, Wang L, et al. COVID-19: Epidemiology, Evolution, and Cross-Disciplinary Perspectives. Trends Mol Med. 2020;26(5):483495. doi: 10.1016/j.molmed.2020.02.008

24. Alsayed R, Kadhom M, Yousif E, et al. An Epidemiological Characteristic of the COVID-19 Among Children. Letters in Applied NanoBioScience. 2020;9(3):1156-64. doi : 10.33263/LIANBS93.11561164

25. Cascella M, Rajnik M, Cuomo A, et al. Features, Evaluation, and Treatment of Coronavirus. 2020 Oct 4. In: StatPearls [Internet]. Treasure Island (FL): StatPearls Publishing; 2020 Jan-. PMID: 32150360

26. D'Amico F, Baumgart DC, Danese S, et al. Diarrhea During COVID-19 Infection: Pathogenesis, Epidemiology, Prevention, and Management. Clin Gastroenterol Hepatol. 2020;18(8):1663-72. doi: 10.1016/j.cgh.2020.04.001

27. $\mathrm{Xu} \mathrm{X}, \mathrm{Wu} \mathrm{X}$, Jiang $\mathrm{X}$, et al. Clinical findings in a group of patients infected with the 2019 novel coronavirus (SARS-CoV-2) outside of Wuhan, China: retrospective case series. BMJ. 2020;368. doi: 10.1136/bmj.m606

28. Pang J, Wang $M$, Ang I, et al. Potential rapid diagnostics, vaccine and therapeutics for 2019 novel coronavirus (2019-nCoV): a systematic review. Journal of clinical medicine. 2020;9(3):623. doi: 10.3390/jcm9030623

29. Lai C, Shih T, Ko W, et al. Severe acute respiratory syndrome coronavirus 2 (SARS-CoV-2) and corona virus disease-2019 (COVID-19): the epidemic and the challenges. International Journal of Antimicrobial Agents. 2020;105924. doi: 10.1016/j.ijantimicag.2020.105924

30. Wölfel R, Corman V, Guggemos W, et al. Virological assessment of hospitalized patients with COVID-2019. Nature. 2020;581(7809):465469. doi: 10.1038/s41586-020-2196-X
31. El Zowalaty M, Järhult J. From SARS to COVID-19: A previously unknown SARS-CoV-2 virus of pandemic potential infecting humansCall for a One Health approach. One Health. 2020;9:100124.ddoi: 10.1016/j.onehlt.2020.100124

32. Feng S, Shen C, Xia N, et al. Rational use of face masks in the COVID-19 pandemic. The Lancet Respiratory Medicine. 2020;8(5):434-436. doi: 10.1016/S2213-2600(20)30134-X

33. Guo X, Wang J, Hu D, et al. Survey of COVID-19 disease among orthopaedic surgeons in Wuhan, People's Republic of China. The Journal of Bone and Joint Surgery. American Volume.] 2020;102(10):847-854. doi: 10.2106/ JBJS.20.00417

34. Eikenberry S, Mancuso M, Iboi E, et al. To mask or not to mask: Modeling the potential for face mask use by the general public to curtail the COVID-19 pandemic. Infectious Disease Modelling. 2020;5:293-308. doi: 10.1016/j.idm.2020.04.001

35. Neupane B, Giri B. Current understanding on the Effectiveness of Face Masks and Respirators to Prevent the Spread of Respiratory Viruses. engrVix; 2020. doi: 10.31224/osf.io/h3wgc

36. Alsayed R, Ali A, Makia R, et al. Challenges Facing Iraq to Tackle the Spread of COVID-19: An Overview. Journal of University of Anbar for Pure Science. 2020;14(2):22-27 doi: 10.37652/ JUAPS.2020.00.0.0

37. Ong S, Tan Y, Chia $P$, et al. Air, surface environmental, and personal protective equipment contamination by severe acute respiratory syndrome coronavirus 2 (SARS-CoV-2) from a symptomatic patient. JAMA. 2020;323(16):161012.Jdoi: 10.1001/jama.2020.3227

38. Al-Dahhan W, Al-Mashhadani M, Raheem R, et al. Iraq Faces the COVID-19 with Limited Health Capabilities and Major Medical Challenges. News and Views. 2020;5(3):1271-74. doi: 10.21931/ $\mathrm{RB} / 2020.05 .03 .19$

39. Yamagishi T. Environmental sampling for severe acute respiratory syndrome coronavirus 2 (SARS$\mathrm{CoV}-2$ ) during a coronavirus disease (COVID-19) outbreak aboard a commercial cruise ship. medRxiv. 2020. doi: 10.1101/2020.05.02.20088567 